\title{
MIR223 wt Allele
}

National Cancer Institute

\section{Source}

National Cancer Institute. MIR223 wt Allele. NCI Thesaurus. Code C82175.

The human MIR223 wild-type allele is located in the vicinity of Xq12 and is 109 bases in length. This allele, which encodes MIR223 RNA, plays a role in development of cancers of the liver and ovary, acute promyelocytic leukemia and chronic myeloid leukemia. 